\title{
KEIKUTSERTAAN PUSTAKAWAN \\ PADA PROGRAM “CALL FOR PAPERS” DALAM SEMINAR PERPUSTAKAAN GUNA MENINGKATKAN KOMPETENSI MENULIS DAN KOMPETENSI LAINNYA
}

\author{
Lenny Fatimah Noviawijayawaty ${ }^{1}$, Elyani Sulistialie, \\ Perpustakaan ITB ${ }^{1}$, Observatorium Bosscha, FMIPA ITB 2 . \\ lenny@lib.itb.ac.id, ely@as.itb.ac.id
}

\begin{abstract}
Abstrak
Mengikuti seminar dapat menambah wawasan dan pengetahuan, hampir semua orang sudah tahu. Hadir dalam seminar dan berpresentasi mungkin tidak semua orang mengalaminya. Kini dengan mengikuti program "Call for Papers", diantaranya dengan mengirim abstrak terlebih dahulu, pustakawan dapat tampil untuk berpresentasi. Pustakawan dapat memilih topik yang dikuasainya dan menyiapkan diri untuk bepergian jika seminar diadakan di luar kota. Dengan menulis artinya pustakawan mendokumentasikan apa yang telah dikerjakan dan pengetahuan yang dimilikinya lalu dengan berpresentasi ia menyampaikan apa yang diketahuinya kepada pustakawan lain. Untuk riset paper ini penulis menggunakan metoda deskriptif analisis dan studi literatur. Tujuan penulisan paper ini adalah untuk mengetahui kompetensi apa saja yang diperoleh dari mengikuti program "Call for Papers" sehingga diharapkan dapat menumbuhkan minat pustakawan untuk menulis dan berpresentasi. Pemahaman atau kompetensi yang diperoleh dengan menghadiri seminar perpustakaan dan mengikuti program "Call for Papers" selain kemampuan menulis diantaranya tentang praktek kepustakawanan, literasi informasi, teknologi informasi dan lain-lain. Semoga pustakawan dapat memanfaatkan program "Call for Papers" untuk pengembangan karirnya.
\end{abstract}

Kata kunci : call for papers, kompetensi, presentasi

\begin{abstract}
Everyone knows that attending a seminar can add insight and knowledge. However attending a seminar and presenting paper may not be experienced by everyone. Now by joining the "Call for Papers" program by sending abstract first, librarians could have a presentation. Librarians can choose topics they master and prepare to travel if the seminar is held outside the city. Writing means librarians document their knowledge and what have been done in the library meanwhile presenting means they convey what they know. This study research aims to explore what competencies are obtained by joining the "Call for Papers" program, in order to foster interest of librarians to write and have a presentation. Understanding and competence obtained by attending seminars and joined to "Call for Papers" program in addition to the ability of write are librarianship practices, information literacy, information technology etc. It is hoped that librarians can take advantage of the "Call for Papers" program for their career development.
\end{abstract}

Keyword : call for papers, competence, presentation

\section{Pendahuluan}

Pustakawan perlu menambah pengetahuan dengan mengikuti seminar, pelatihan dan lain-lain. Dengan mengikuti seminar perpustakaan dan mengikuti program "Call for Papers", pustakawan akan mendapat nilai tambah dari karya tulisnya.

Jika kita "googling" istilah "Call for Papers Perpustakaan 2019" akan ditemukan beberapa kesempatan untuk mengikuti seminar dan mengirimkan paper untuk dipresentasikan. Pada tahun 2019 ada beberapa universitas dan institusi yang menyelenggarakan seminar yakni Universitas Jember pada bulan Juli 2019, LIPI pada bulan Agustus 2019, SNIPER di Bandar Lampung dan UIN Sunan Kalijaga Yogayakarta pada bulan Oktober, dan lain-lain. Hal tersebut meng-gambarkan bahwa pustakawan dapat menentukan seminar mana yang 
akan diikutinya. Pustakawan dapat memilih topik yang dikuasainya dan menyiapkan diri untuk bepergian jika seminar diadakan di luar kota.

Tujuan penulisan paper ini untuk mengetahui kompetensi apa saja yang diperoleh dengan mengikuti seminar dan program "Call for Papers, dan persiapan apa saja yang diperlukan.

\section{Kajian Pustaka/Pengembangan Hipotesis}

Istilah "Call for Papers" sudah tidak asing lagi bagi pustakawan dan ilmuwan namun arti yang baku belum ada. Kamus Webster menyatakan babwa "call for" berarti untuk meminta (Webster New International Dictionary., $\left.2^{\text {nd }} . e d, 1909\right)$ dan "paper" berarti bahan tulisan. Maka "call for papers" dapat di artikan, merupakan undangan untuk mengirimkan bahan tulisasn atau artikel yang di sesuaikan dengan tema pengundang. Kegiatan ini sangat berguna bagi pustakawan untuk pengembangan karirnya dalam hal menulis sehingga pustakawan yang rajin menulis kompetensinya akan sangat baik. Seorang pustakawan khususnya pustakawan fungsional diwajibkan membuat makalah atau artikel untuk memenuhi angka kredit guna kenaikan pangkat.

Adapun tentang menulis Hardiningtyas (2015) dalam bukunya "Pustakawan \& Angka Kredit" menyatakan bahwa:

- Menulis bagi pustakawan merupakan suatu keharusan jika tidak mau ketinggalan kereta

- Pustakawan bisa menuliskan setiap kegiatan yang dilakukan dengan segala pernak-perniknya.

- Hasil tulisan pustakawan sebagai wujud keprofesionalan diri sehingga dapat meningkatkan pengembangan profesi, juga sebagai sarana peningkatan karir.
Selain menulis artikel untuk diterbitkan di jurnal atau menulis buku, akhir-akhir ini dalam penyelenggaraan seminar perpustakaan di Indonesia juga diadakan program "Call for Papers" di mana pustakawan diundang untuk membuat paper atau artikel ilmiah dan mempresentasikanya. Kesempatan tersebut tentu sangat baik bagi pustakawan, karena akan mendapat nilai kredit untuk presentasinya, apa lagi jika karya tulisnya dipublikasikan dalam prosiding atau jurnal ilmiah.

Penulis pertama (Lenny Fatimah) telah mengikuti program "Call for Papers" dalam seminar yang diselengarakan di kampus UPI pada tahun 2015 dan 2016 serta dalam seminar yang diselenggarakan oleh UNILA di Bandar Lampung pada tahun 2017. Penulis kedua (Sulistialie) pernah menyampaikan papernya dalam pertemuan pustakawan atronomi internasional tahun 2014 (eventi.oacn. inaf.it/lisa7); dan presentasi "call for papers" lainnya tahun 2015, 2016, 2017 dan 2019.

Seperti dinyatakan oleh Hollister (2014): Authors must see, understand, and be able to articulate how their work relates to the works of others in the field, how it fits within the framework of contemporary theory, and how it contributes to an ongoing discourse within their particular area of practice of study. Penulis harus melihat, memahami dan dapat mengartikulasikan bagaimana pekerjaan mereka berhubungan dengan karya-karya orang lain di lapangan, bagaimana hal itu cocok dalam kerangka teori kontemporer, dan bagaimana hal itu berkontribusi pada wacana yang sedang berlangsung dalam bidang bidang mereka. Pustakawan hendaknya mengikuti perkembangan ilmu pengetahuan.

Dari kegiatan menulis artinya pustakawan mendokumentasikan pengetahuan yang dimiliki dan dengan berpresentasi ia menyampaikan apa yang diketahuinya. Dengan mengikuti seminar pustakawan mendapat pengetahuan baru dari pembicara utama dan dari paper lainnya. 


\section{Metode Penelitian}

Untuk memaparkan paper ini penulis menggunakan metoda deskriptif analisis dan studi literature yang bersifat kualitatif, yakni "mengumpulkan, mengintegrasikan dan menyajikan data dari berbagai sumber bukti sebagai bagian dari studi" Ying (2015). Data diperoleh dari keikutsertaan penulis pada program "Call for Papers" di beberapa kota.

\section{Hasil dan Pembahasan}

Informasi tentang seminar dan kesempatan mengikuti program "Call for Papers" kini tidak hanya dapat ditemukan pada laman penyelenggara atau institusi. Whatsapp Group juga biasanya menginformasikan kesempatan itu untuk diketahui oleh rekan-rekan lainnya.

Perlu diingat tenggat waktu pengiriman abstrak dan papernya Abstrak bagaikan rumah transparan, di mana orang bisa melihat apa saja isinya. Oleh karena itu abstrak hendaknya menampilkan keunggulan dari paper kita, usulan, hasil utama dan metoda pengumpulan data atau penulisannya. Berikut adalah beberapa program "Call for Papers" yang diikuti:

TABEL 1

PRESENTASI “CALL FOR PAPERS" PADA SEMINAR YANG DIIKUTI

\begin{tabular}{|c|c|c|c|c|}
\hline No & Tema Seminar & $\begin{array}{c}\text { Penyelengga } \\
\text { Raan }\end{array}$ & Judul Paper & Hasil Yang Diperoleh \\
\hline 1 & $\begin{array}{l}\text { Open Science at the } \\
\text { Frontiers of } \\
\text { Librarianship }\end{array}$ & $\begin{array}{l}\text { LISA 7, Observatory } \\
\text { of Capodimonte, } \\
\text { Napoli. Juni } 2014\end{array}$ & $\begin{array}{l}\text { New Roles of Librarian of } \\
\text { Bosscha Observatory } \\
\text { (E. Sulistialie) }\end{array}$ & $\begin{array}{ll}- & \text { Terbit pada ASP } \\
\text { Conference Series 492, } \\
2015 \\
\text { - Tergabung dalam } \\
\text { Astrolib Digest }\end{array}$ \\
\hline 2 & $\begin{array}{l}\text { Library Move On: } \\
\text { Bangga Menjadi } \\
\text { Profesional di dunia } \\
\text { Perpustakaan dan } \\
\text { Informasi }\end{array}$ & $\begin{array}{l}\text { ISIPII \& FPPT, } \\
\text { Bandung Agustus } \\
2015\end{array}$ & $\begin{array}{l}\text { Penerbitan buku Librarian } \\
\text { Speaking melalui Independent } \\
\text { Publisbing". (E. Sulistialie \& } \\
\text { Lenny FN) }\end{array}$ & $\begin{array}{ll}\text { - } & \text { Terbit di Prosidings } \\
\text { - } & \text { Sertifikat }\end{array}$ \\
\hline 3 & $\begin{array}{l}\text { Reference Manager } \\
\text { Meningkatkan } \\
\text { Kualitas karya } \\
\text { Ilmiah di Perguruan } \\
\text { Tinggi }\end{array}$ & $\begin{array}{l}\text { FPPT Jawa Barat, } \\
\text { Bandung } 2016\end{array}$ & $\begin{array}{l}\text { Pengembangan Layanan } \\
\text { Reference di Perpustakaan } \\
\text { SAPPK dan Observatorium } \\
\text { Bosscha FMIPA ITB: Studi } \\
\text { Perbandingan } \\
\text { (Lenny FN \& Sulistialie) }\end{array}$ & Sertifikat Pemakalah \\
\hline 4 & $\begin{array}{l}\text { Pustakawan dan } \\
\text { Perpustakaan } \\
\text { Kreatif Inovatif di } \\
\text { era Digital }\end{array}$ & $\begin{array}{l}\text { UNAIR Surabaya, } \\
\text { Mei } 2017\end{array}$ & $\begin{array}{l}\text { Literasi Informasi } \\
\text { Astronomi dan Pariwisata } \\
\text { dengan Buku Indonesia } \\
\text { Bangeu...tz } \\
\text { (E. Sulistialie \& Ipah } \\
\text { Saripah) }\end{array}$ & $\begin{array}{ll}\text { - } & \text { Sertifikat Pemakalah } \\
\text { - } & \text { Terbit di Prosiding }\end{array}$ \\
\hline 5 & $\begin{array}{l}\text { Semiloka Nasional } \\
\text { Inovasi } \\
\text { Perpustakaan }\end{array}$ & $\begin{array}{l}\text { UNILA, Bandar } \\
\text { Lampung } 2017\end{array}$ & $\begin{array}{l}\text { - Menuju Integrasi } \\
\text { Database Perpustakaan } \\
\text { dalam Meningkatkan } \\
\text { Layanan Perpustakaan } \\
\text { pada Pemustaka: Studi } \\
\text { Kasus UPT } \\
\text { Perpustakaan ITB } \\
\text { (Lenny Fatimah N) } \\
\text { - Kontribusi Pustakawan } \\
\text { ITB untuk Mendukung } \\
\text { Perpustakaan Sebagai } \\
\text { Inkubator Inovasi dan } \\
\text { Kreativitas Sumber } \\
\text { Daya Manusia serta } \\
\text { Teknologi Informasi } \\
\text { (Ena Sukmana; E. } \\
\text { Sulistialie) }\end{array}$ & $\begin{array}{ll}\text { - } & \text { Sertifikat Pemakalah } \\
\text { - } & \text { Terbit di Jurnal Tawit } \\
& \text { Pustaka }\end{array}$ \\
\hline 6 & $\begin{array}{l}\text { AICONICS: } \\
\text { Cultural Literacy } \\
\text { and Islam in the Post } \\
\text { Truth Society }\end{array}$ & $\begin{array}{l}\text { UIN Sunan } \\
\text { Kalijaga } \\
\text { Yogyakarta, } \\
\text { Oktober } 2019\end{array}$ & $\begin{array}{l}\text { Information Literacy for } \\
\text { Female Population around } \\
\text { Bosscha Observatory" } \\
\text { (E. Sulistialie, dkk) }\end{array}$ & $\begin{array}{ll}\text { - } & \text { Sertifikat Pemakalah } \\
\text { - } & \text { Akan Terbit di } \\
& \text { Jurnal }\end{array}$ \\
\hline
\end{tabular}


Dengan mengikuti seminar, pustakawan bertambah pengetahuan dan wawasan. Kegiatan berpresentasi ataupun sebagai narasumber pada seminar pada program "Call for Papers", mengasah kemampuan pustakawan dalam menulis dan tampil di hadapan banyak orang. Adapun pengetahuan yang diperoleh dari seminar diatas diantaranya tentang permasalahan perpustakaan astronomi, kompetensi pustakawan, perihal Reference Manager, literasi informasi, sistem perpustakaan dan kontribusi pustakawan serta tentang literasi budaya Islam. Pengetahuan dan wawasan dapat diperoleh dari paparan keynote speakers atau membaca paper dari sesama pustakawan yang diterbitkan dalam prosiding

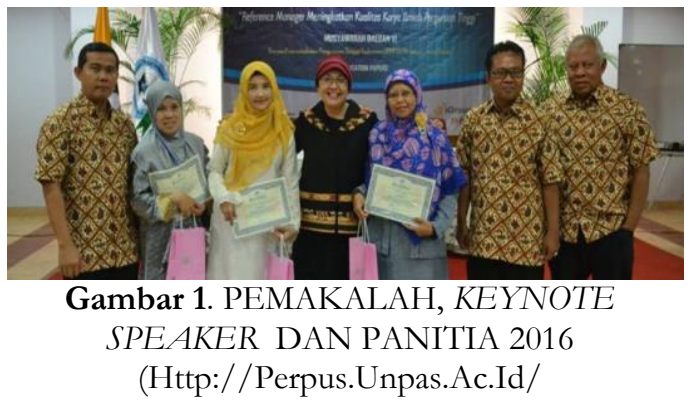

\section{Kesimpulan}

Pemahaman dan kompetensi yang diperoleh dengan menghadiri seminar perpustakaan serta mengikuti program "Call for Papers" selain kemampuan menulis diantaranya adalah tentang praktek kepustakawanan, literasi informasi, teknologi informasi dan lain-lain tergantung tema seminar yang diikutinya. Diharapkan pustakawan dapat memanfaatkan program "Call for Papers" untuk pengembangan karinny.

Abstrak bagaikan rumah transparan, di mana orang bisa melihat apa saja isi didalamnya. Oleh karena itu abstrak hendaknya menampilkan keunggulan dari paper kita, usulan, hasil utama dan metoda pengumpulan data atau penulisannya. Abstrak harus ditulis dengan ringkas dan jelas. Adapun peningkatan kompetensi menulis dengan mengikuti program "Call for Papers" yakni pustakawan harus membaca literatur dan memaparkan pemikirannya dalam bentuk tulisan. Peningkatan kompetensi lainnya diperoleh dari mendengarkan paparan dari keynote speakers dan pemateri lainnya.

Peningkatan kompetisi menulis karya ilmiah sangatlah penting untuk kenaikan pangkat/jabatan bagi pustakawan fungsional sehingga penulisan artikel ilmiah sangatlah menunjang seorang pustakawan dalam pening-katan karirnya yang professional dan kompetensi yang mumpuni.

\section{Referensi/Daftar Pustaka}

Hardiningtyas, (2015). Pustakawan \& Angka Kredit. Yogyakarta: Ladang Kata

Harris, William Torrey. (1909). Webster's New International Dictionary. $2^{\text {nd }} . e d$. Springfield :

Preface. G. \& C. Merriam.

Hollister, C.V (2014). Handbook of

Academic Writing. Chicago, ACRL

Yin, Robert K. (2011). Qualitative Research:

From Start to Finish. New York: Guilford

\section{BIODATA:}

\section{Rd. Lenny Fatimah Noviawijayawati}

Sebagai Pustakawan Ahli Madya, dan sudah bekerja di Institut Teknologi Bandung sejak 1987 di Perpustakaan Perencanaan Wilayah dan Kota SAPPK dari tahun 1987-

2016. Kemudian pada pertengan tahun 2016 pindah ke UPT Perpustakaan Pusat ITB sampai sekarang.

Ketua Ikatan Pustakawan Indonesia

Daerah Kota Bandung tahun 2011-2015

No yang dapat di hubungi : 08122472751

\section{Elyani Sulistialie}

Bekerja di Observatorium Bosscha sejak

1994. Menulis 5 buku yakni: Reading at Bosscha Village. Yogyakarta: Leutika Prio, 2015; Librarian Speaking/writer \& editor. Yogyakarta: Leutika Prio, 2015; Indonesia Bangeu...t t: Journey of A Mother and Son. Yogyakarta: Ladang Kata, 2017; Bandung Pissaaan: Serpihan Cerita Unique Sekolah Jadul/writer\& editor. Yogyakarta: Azyan 
Mitra Media, 2018; Bambang Hidayat: Derap Langkeah Seorang Astronom (bersama Siti Fatima). Bandung: ITB Press, 2019

Akhir tahun 2018 menerima piagam penghargaan dari Kepala Desa Lembang sebagai “Tokob Pelopor Literasi Keluarga Desa
Lembang". Awal Juli 2019 mendapat penghargaan sebagai Juara Harapan I dalam Lomba Pustakawan Berprestasi Jawa Barat.

Kontaknya: ely.sulistialie27@gmail.com dan handphone 081931365084. 